\section{DIARY}

\section{APRIL}

HC2010 health informatics conference and exhibition Date: 27-29 April 2010 Venue: International Conference Centre (ICC), Birmingham www.hc2010.co.uk

\section{MAY}

British Society for Restorative Dentistry 42nd Spring Scientific Meeting Date: 7-8 May 2010

Venue: Lensbury, Teddington Lock Email: charlotte.o'sullivan@UHBristol.nhs.uk

Dental Sedation Teachers

Group Annual Symposium 2010

Date: 14-15 May 2010

Venue: Dublin Dental School and Hospital,

Trinity College Dublin, Ireland

Email:mary.clarke@dental.tcd.ie www.dstg.co.uk

British Dental Conference and Exhibition 2010

Date: 20-22 May 2010

Venue: Arena and Convention Centre, Liverpool

Tel: 08701666625

Email:bda@delegate.com

www.bda.org

\section{JUNE}

Annual Meeting of the European Society of Dental Ergonomics

Date: 4-5 June 2010

Location: Ghent University Hospital,

Ghent, Belgium

Email: secretary-general@esde.org

www.esde.org

Training essentials - Managing stress in yourself and your team

Date: 17 June 2010

Venue: BDA, London

Email: events@bda.org

Welsh Rural Postgraduate Unit, Institute of Rural Health,

11th Annual Rural Dental Conference

Date: 25 June 2010

Venue: Gregynog Hall, Newtown, Mid Wales Tel: 01686650800

BDA Seminar - Introduction to

being an associate

Date: 25 June 2010

Venue: BDA, London

www.bda.org/events

\section{STUDENT PRIZE WINNER}

Sameer Patel has been awarded the Student Essay Prize from the Society for the Advancement of Anaesthesia in Dentistry (SAAD).

Dental students worldwide are invited to submit an essay on any subject related to conscious sedation, general anaesthesia, analgesia or anxiety control in dentistry. Sameer's essay dealt with safety aspects of the use of nitrous oxide in conscious sedation for dentistry.

Every year a prize of $£ 300$ is awarded for the best essay and presented at the SAAD Annual Conference. The essays are published in the $S A A D$ Digest for the benefit of the SAAD membership. There is also an annual competition for the best essay written by a dental nurse.

For more information please visit www.saad.org.uk/awards.

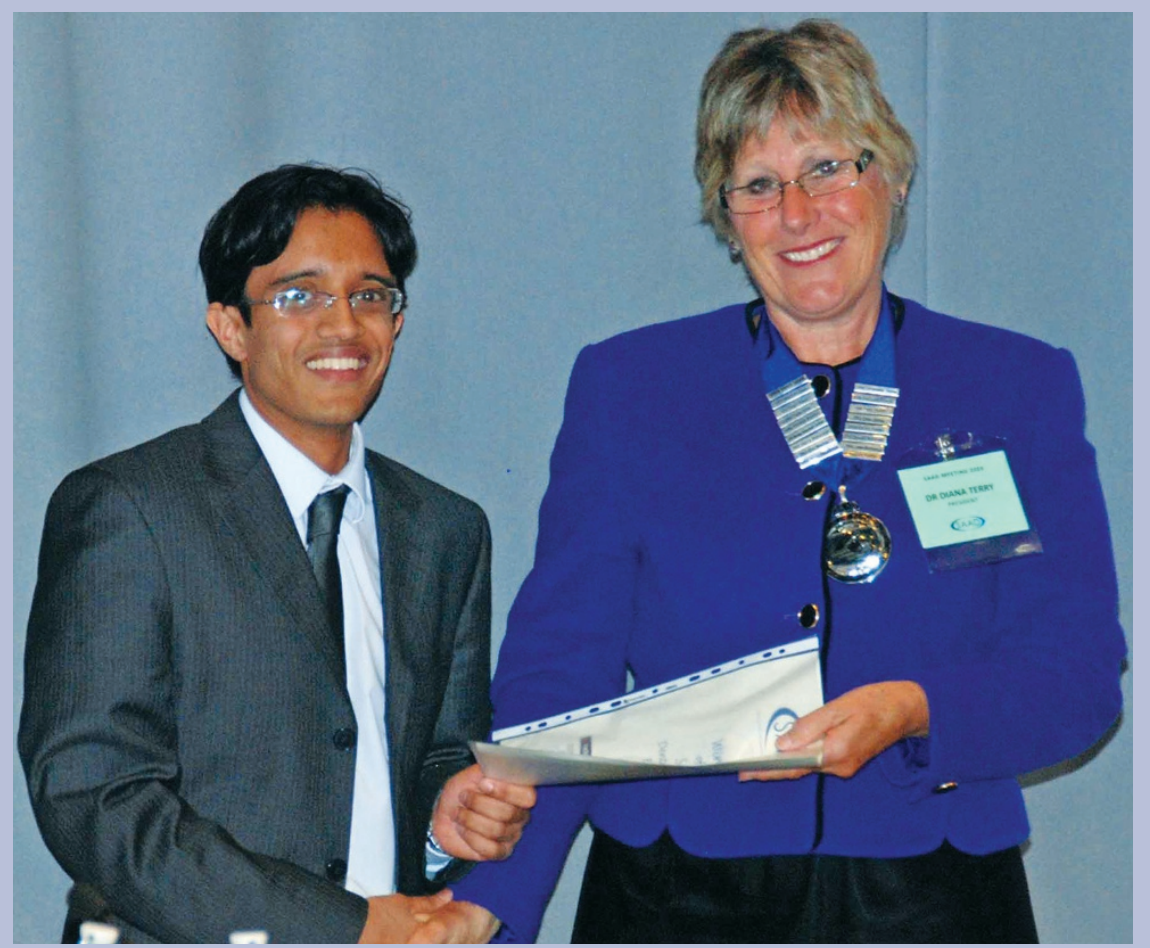

Sameer Patel receiving his award from Diana Terry, President of SAAD

\title{
SPECIAL CARE DENTISTRY DEADLINE APPROACHES
}

The General Dental Council (GDC) is reminding dentists that there are now only six months until the end of the transitional period for joining the Special Care Dentistry list.

The list first opened on 1 October 2008 and the transitional period will close on 30 September 2010. After this date, UK applicants will need to hold a Certificate of Completion in Specialist Training to join the list. Registered dentists can currently apply to join the list on the basis of the relevant specialist training, qualifications and experience they have acquired to date.

Special care dentistry is concerned with improving the oral health of individuals and groups in society who have a physical, sensory, intellectual, mental, medical, emotional or social impairment or disability, or a combination of these. In particular, this area of dentistry focuses on adults and adolescents requiring special care.

Since the list opened in October 2008, 119 dentists have joined. The GDC is encouraging other appropriately trained, qualified and experienced dentists who wish to join the list to submit their applications as soon as possible to avoid unnecessary delays or missing the deadline of the transitional period on 30 September.

Dentists wishing to join the list can download an application pack from the GDC website www.gdc-uk.org or contact the GDC registration team by email at assessments@gdc-uk.org or by phone on 02073443741. 